\title{
Effect of Yttria on the Phase Formation and Sintering of $\mathrm{HA}-\mathrm{Al}_{2} \mathrm{O}_{3}$ Biocomposites
}

\begin{abstract}
K.E. ÖKSÜZ* AND A. ÖZER
Cumhuriyet University, Department of Metallurgical and Materials Engineering, 58140, Sivas, Turkey

Hydroxyapatite is very-well known as the main component of hard tissues and, as such, it has attracted much attention by researchers in the recent decades. This study was aimed to present the characterization of $\mathrm{Y}_{2} \mathrm{O}_{3}$ doped 50 wt. $\%$ hydroxyapatite -50 wt. $\% \mathrm{Al}_{2} \mathrm{O}_{3}$ composite materials fabricated at relatively high temperature of $1600^{\circ} \mathrm{C}$. Hydroxyapatite powder was obtained from bovine bones via calcination and ball milling technique. Fine powders $(\leq 1 \mu \mathrm{m})$ of hydroxyapatite/ $\mathrm{Al}_{2} \mathrm{O}_{3}$ were admixed with 0.5 and 1 wt.\% $\mathrm{Y}_{2} \mathrm{O}_{3}$ powders. Powder compacts were sintered at $1600^{\circ} \mathrm{C}$ for $4 \mathrm{~h}$ in air atmosphere. The field emission scanning electron microscopy, energy-dispersive spectroscopy and X-ray diffraction studies following the relative density measurements were conducted. Moreover, the microhardness was studied as the mechanical property of sintered samples. The effect of increasing $\mathrm{Y}_{2} \mathrm{O}_{3}$ content on surface morphology, elemental distribution and phase evaluation was investigated in hydroxyapatite $/ \mathrm{Al}_{2} \mathrm{O}_{3}$ biocomposite materials. It was found that by increasing $\mathrm{Y}_{2} \mathrm{O}_{3}$ content, the relative density increased up to $98.8 \%$, while the hardness increased to $863 \mathrm{HV}_{(0.2)}$. The main phases, which were found, are Hibonite - $\mathrm{CaO}\left(\mathrm{Al}_{2} \mathrm{O}_{3}\right)_{6}$ and beta-tricalcium phosphate $-\mathrm{Ca}_{3}\left(\mathrm{PO}_{4}\right)_{2}$, according to X-ray diffraction pattern.
\end{abstract}

DOI: 10.12693/APhysPolA.131.576

PACS/topics: 87.85.J-, 87.85.jj, 81.07.-b, 88.30.mj, 87.85.Lf

\section{Introduction}

Nowadays, more and more bone diseases such as bone infections, bone tumors, and bone loss require bone regeneration. Bone tissue engineering is a complex and dynamic process that initiates with migration and recruitment of osteoprogenitor cells followed by their proliferation, differentiation, matrix formation along with remodeling of the bone $[1,2]$. Bone scaffold is typically made of porous biodegradable materials that provide the mechanical support during repair and regeneration of damaged or diseased bone. Researches on bone tissue engineering over the past decades have inspired innovation in novel materials, processing techniques, performance evaluation, and applications. Biocompatible scaffolds with controlled porosity and tailored properties are available today due to innovation in scaffold fabrication using advanced technologies.

Hydroxyapatite $\left(\mathrm{HA}, \mathrm{Ca}_{10}\left(\mathrm{PO}_{4}\right)_{6}(\mathrm{OH})_{2}\right)$ material is very popular for bone restorations since it accelerates the bone growth around the implant due to its chemical and crystallographic similarity to human carbonated apatite [3]. Biomaterials of synthetic HA are highly reliable but the synthesis of HA is often complicated and expensive. Bioceramics of naturally derived biological apatites are more economic. Extensive studies have indicated that HA is biocompatible with hard tissues of human beings and exhibits osteoconductive properties [4-7].

Nevertheless, the mechanical properties of HA are poor, especially in wet environment. Therefore, ceramics of pure HA cannot be suggested for use in heavy-loaded

*corresponding author; e-mail: kerimemreoksuz@gmail.com implants, such as artificial bones or teeth. They can only be used at non-loading applications; such as graft materials.

To improve mechanical reliability of HA-ceramics, i.e. to increase their fracture toughness, incorporation of metallic materials, ceramic oxides [8-10] or fibers can be used. The reinforcement of HA matrices with ceramic particles revealed to have considerable potential for improving the mechanical properties [11]. Among the many ceramics used in orthopedics, alumina $\left(\mathrm{Al}_{2} \mathrm{O}_{3}\right)$ is classified as a bioinert material with excellent friction and wear properties, as well as minimal tissue reaction [12]. In this study, we present the production and characterization of HA- $\mathrm{Al}_{2} \mathrm{O}_{3}$ composites, produced via sintering of powder compacts. Bovine derived $\mathrm{HA}$ was used and $\mathrm{Y}_{2} \mathrm{O}_{3}$-doping was at 0.5 and 1 wt.\%. The microstructural observations, phase evaluation, microhardness-density and crystallographic analysis were carried out for the produced samples.

\section{Materials and experimental procedure}

Bovine femoral bones were cut into small pieces and deproteinized in an alkali solution of $1 \mathrm{wt} . \%$ sodium hypochlorite. After washing and drying, the bone pieces were calcined at $850^{\circ} \mathrm{C}$ for $4 \mathrm{~h}$ in air to totally eliminate any risk of transmitting diseases. The calcined bone pieces were crushed and then ball-milled until fine powders of apatite (BHA $\left.d_{\text {mean }} \leq 1 \mu \mathrm{m}\right)$ was obtained [13-17]. BHA-powders were mixed with 50 wt.\% of $\mathrm{Al}_{2} \mathrm{O}_{3} d_{\text {mean }} \leq 1 \mu \mathrm{m}$ fine powder. In this manner, matrix composition which will be used in the experimental study was prepared.

0.5 and 1 wt. $\% \mathrm{Y}_{2} \mathrm{O}_{3}$ were correspondingly mixed with $\mathrm{HA}$ and $\mathrm{Al}_{2} \mathrm{O}_{3}$ powders. These samples are denoted as BHAA, 0.5BHAA and 1BHAA respectively. The powder 
mixtures were well homogenized by ball milling in ethyl alcohol using a jar and balls made of zirconia (200 cycles $/ \mathrm{min}, 24 \mathrm{~h}$ ) with a ball to powder ratio of $20: 1$. The suspensions were dried and the obtained powders were uniaxially pressed at $350 \mathrm{MPa}$ to form cylindrical pellets with a diameter of $13 \mathrm{~mm}$ and height of $10 \mathrm{~mm}$, according to the British Standard [18].

The green bodies were sintered at $1600^{\circ} \mathrm{C}$ for $4 \mathrm{~h}$ in static air atmosphere in an electric furnace. Micro-hardness tests were done with a Vickers micro-hardness testing equipment (Shimadzu micro-hardness tester type M, Japan; load of $1.961 \mathrm{~N}$; the results were the average of ten different indentation measurements).

The sintered samples were analyzed using field emission gun scanning electron microscope (FEG-SEM, Tescan Mira3 XMU, Czechia) and energy dispersive spectrometer (EDS, AZtec IE, U.K.) for further investigation of grain morphology, shape, size and phase formation. The FE-SEM samples were examined by secondary electron detector at an accelerating voltage of $15-20 \mathrm{kV}$. EDS was used to determine their surface composition in $\mathrm{a} \approx 0.01 \mathrm{~mm}^{2}$ area, at source energy of $10 \mathrm{keV}$. X-ray Diffractometer (Rigaku D/MAX/2200/PC ) with a monochromatic $\mathrm{Cu}-\mathrm{K}_{\alpha}$ radiation $(\lambda=1.5408 \AA)$ with an accelerating voltage of $40 \mathrm{kV}$ and a current of $40 \mathrm{~mA}$ was used over a $2 \theta$ range from $20^{\circ}$ to $80^{\circ}$ to characterize the crystal structure of the sintered samples.

\section{Results and discussion}

\subsection{Fabrication of raw powders}

Figure 1 represents the FE-SEM image of initial powders after ball milling for $24 \mathrm{~h}$. As illustrated in Fig. 1a the powders have relatively narrow particle size distribution without yttria addition. This could be attributed to the very hard and brittle nature of bovine bone and aluminum oxide.

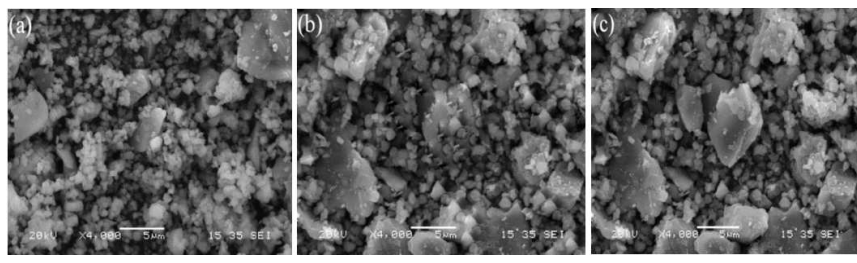

Fig. 1. FE-SEM image of initial powders after ball milling for $24 \mathrm{~h}$. (a) BHAA, (b) 0.5BHAA, (c) 1BHAA. $\dagger \mathrm{HA}$ was derived from freshly-extracted bovine femoral bones. $\mathrm{Al}_{2} \mathrm{O}_{3}$ and $\mathrm{Y}_{2} \mathrm{O}_{3}$ are commercial.

Figure $1 b$ and $c$ shows the existence of yttria by increasing weight percent. By increasing yttria content the powders, especially $\mathrm{Al}_{2} \mathrm{O}_{3}$ are in the tendency of formation of Al-Y and Ca-P-Y related phases which are more ductile than bovine bone and aluminum oxide. This is also evident from wide particle size distribution.

\subsection{Phase evaluation}

The X-ray diffraction patterns of the bioceramic composites sintered at $1600^{\circ} \mathrm{C}$ for $4 \mathrm{~h}$ are summarized in
Fig. 2. Two crystalline phases, namely Hibonite $-\mathrm{CaO}$ $\left(\mathrm{Al}_{2} \mathrm{O}_{3}\right)_{6}$ and beta-tricalcium phosphate $-\mathrm{Ca}_{3}\left(\mathrm{PO}_{4}\right)_{2}$, with varying peak intensities, can be detected in the patterns. In all cases, the diffractograms have predominantly registered the Hibonite phase $-\mathrm{CaO}\left(\mathrm{Al}_{2} \mathrm{O}_{3}\right)_{6}$, matched in every sample (ICSD card no. 76-0665), which is due to the dissolution of $\mathrm{CaO}$ from $\mathrm{HA}$ and its reaction with $\mathrm{Al}_{2} \mathrm{O}_{3}$ which makes 50 wt.\% in the composite (see Fig. $2 \mathrm{a}-\mathrm{c}$ ).

X-ray diffraction patterns of $\mathrm{HA}-\mathrm{Al}_{2} \mathrm{O}_{3}$ composite powders show that the peaks correspond to $\mathrm{HA}$ and $\mathrm{Al}_{2} \mathrm{O}_{3}$ phases, confirming that $\mathrm{Al}_{2} \mathrm{O}_{3}$ is effectively incorporated into the HA matrix by forming hibonite. Another registered major phase was beta-tricalcium phosphate. Increasing crystallinity (increase of the peak intensities) in Fig. 2c is attributed to the formation of Ca-Al related phases, accompanying tricalcium phosphate, as previously indicated in Fig. $2 \mathrm{a}$ and b. $\mathrm{CaY}_{2} \mathrm{O}_{3}$ could not be detected in the XRD patterns after sintering, as a pure substance, suggesting that $\mathrm{Y}^{3+}$ ions are dissolved in the HA lattice and sat at interstitial positions, as expected, because of the size difference of their ionic radii [19].

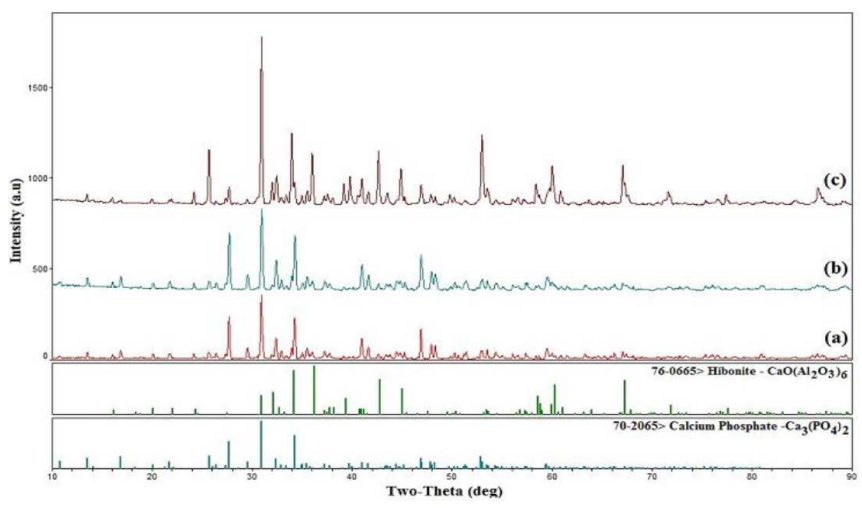

Fig. 2. XRD patterns of biocomposite samples produced with various amounts of $\mathrm{Y}_{2} \mathrm{O}_{3}$, after sintering at temperature of $1600{ }^{\circ} \mathrm{C}$ for $4 \mathrm{~h}$. (a) BHAA, (b) 0.5BHAA, (c) 1BHAA.

\section{3. $S E M$ and EDS analyses}

The surface morphology of the BHAA- $\mathrm{Y}_{2} \mathrm{O}_{3}$ biocomposites was examined by FE-SEM (SEI) equipped with an EDS. The EDS spectra were observed with an image analyzing program. As seen from Fig. 3a and b, the matrix phase underwent a solid state reaction with a little amount of inter-layer liquid phase coming from the formation of hibonite phase, which is a binary solid compound of $\mathrm{CaO}-\mathrm{Al}_{2} \mathrm{O}_{3}$, with higher alumina content. The sintering surface observed in Fig. 3a, seems to show uncompleted solid reaction with smooth and growing regions.

Figure $3 \mathrm{c}$ and d illustrates the $0.5 \mathrm{Y}_{2} \mathrm{O}_{3}$ added BHAA. The surface becomes smoother with small grains that complete the spreading glassy phase and even forming some grown single phase hexagonal structures of Al-Y phases, leading to the existence of new phases in XRD 
pattern. Since the amount of Al-Y and Ca-Y-P related phases is less than 2-3 vol.\%, the XRD pattern cannot show the corresponding phases.

Figure $3 \mathrm{e}$ and $\mathrm{f}$ shows the $1 \mathrm{wt} . \% \mathrm{Y}_{2} \mathrm{O}_{3}$ added BHAA, sintered at $1600^{\circ} \mathrm{C}$. The surface becomes smoother with increasing amount of $\mathrm{Y}_{2} \mathrm{O}_{3}$ by liquid phase formation at high temperature. The increasing $\mathrm{Y}_{2} \mathrm{O}_{3}$ content increases the glassy phase and also the hexagonal shaped hibonite and other related phases to a much extent. The surface was coated with a thin layer of $\mathrm{Ca}-\mathrm{Al}-\mathrm{P}$ liquid phase, which acts as a seed liquid for the formation of other single crystal of dissolved elements. The thermodynamic stability of elements at elevated temperature specifies the formation as the $\mathrm{Ca}-\mathrm{Y}-\mathrm{Al}-\mathrm{P}$ deficient phases and the $\mathrm{Al}$ $\mathrm{Y}$ phases, as can be concluded from the $2 \theta$ peak at $26.1^{\circ}$.
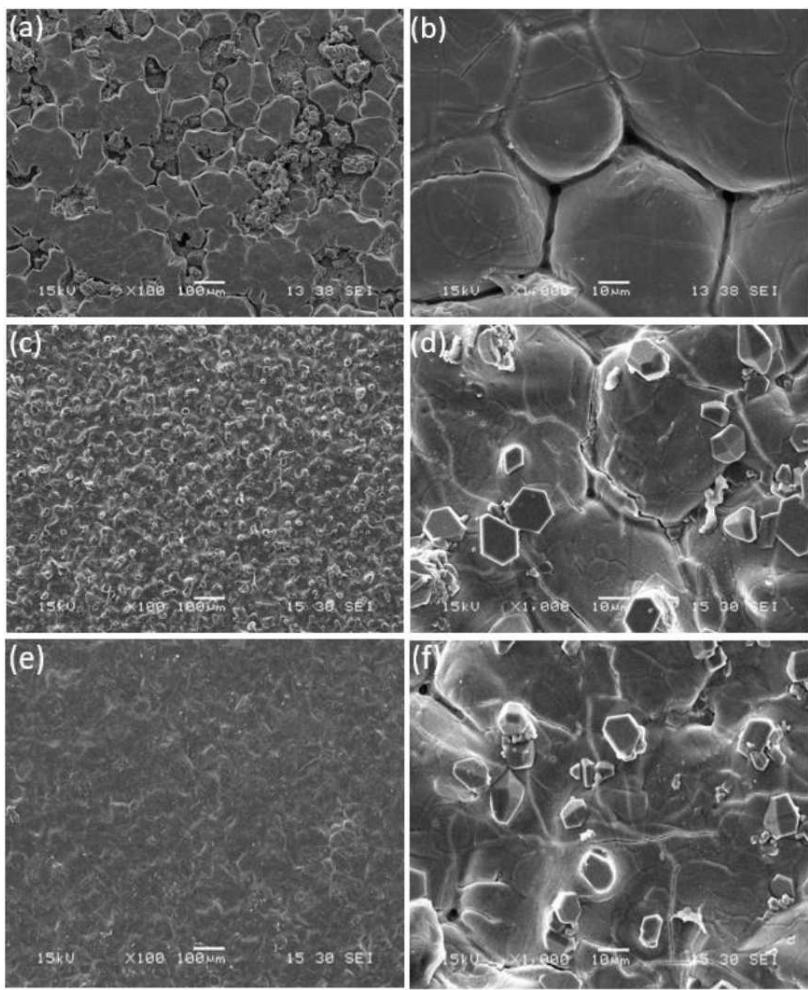

Fig. 3. FE-SEM images of the BHAA- $\mathrm{Y}_{2} \mathrm{O}_{3}$ biocomposites sintered at $1600^{\circ} \mathrm{C}$ for $4 \mathrm{~h}$. (a, b) BHAA, (c, d) 0.5BHAA, (e, f) 1BHAA.

The EDS analysis, as seen from Fig. $4 \mathrm{a}^{-} \mathrm{c}$, was carried out for regions from the images in Figure $3 b, d$ and $f$, respectively. The increasing amount of $\mathrm{Y}$ increases the liquid phase and also the dissolution and spreading of $\mathrm{Y}$, as seen from EDS analysis. The inset tables represent the elemental weight ratios of sintered biocomposites with the increasing amount of $\mathrm{Y}$.

\subsection{Micro-hardness and relative density of composites}

The impact of yttria on BHAA matrix was evident in the micro-hardness analysis results. The obtained
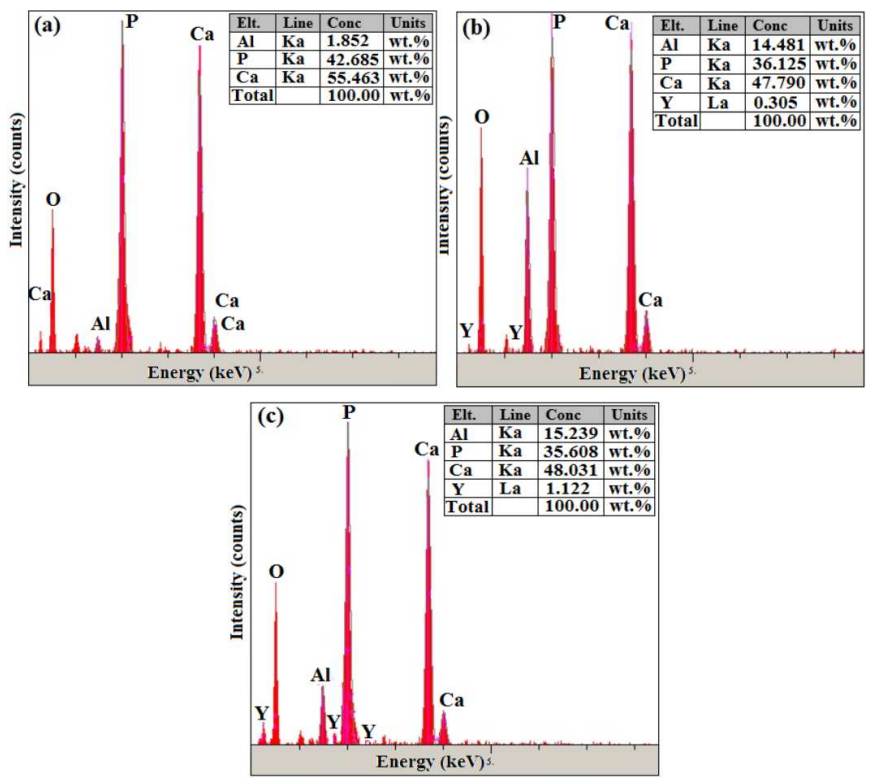

Fig. 4. The EDS spectra of the surfaces of (a) BHAA, (b) 0.5BHAA, (c) 1BHAA biocomposites sintered at $1600^{\circ} \mathrm{C}$ for $4 \mathrm{~h}$

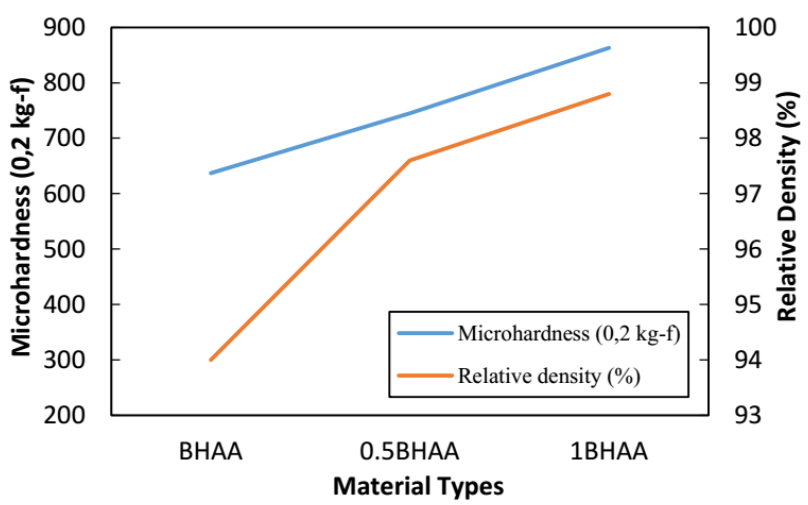

Fig. 5. Variations in relative density and microhardness of $\mathrm{HA} / \mathrm{Al}_{2} \mathrm{O}_{3}$ composites with different $\mathrm{Y}_{2} \mathrm{O}_{3}$ contents.

micro-hardness values are considerably higher than those of the BHAA matrix samples. Hardness of composites increased considerably with the introduction and with the increase of the $\mathrm{Y}_{2} \mathrm{O}_{3}$ addition from 0.5 wt.\% to 1 wt.\%. These have increased from $637 \pm 18.45 \mathrm{HV}$, to $745 \pm 14.1 \mathrm{HV}$ and $863 \pm 8.6 \mathrm{HV}$ for the BHAA matrix, 0.5BHAA and 1BHAA samples, respectively. This might be due to finer $\mathrm{Y}_{2} \mathrm{O}_{3}$ particles and achievement of enough bonding between BHAA matrix, accompanied with the increasing glassy phase amount. The increasing amount of $\mathrm{Y}_{2} \mathrm{O}_{3}$ also leads to the appearance of new phases, as mentioned before for the liquid phase formation, as seen in Fig. 3b, d and f. The grain boundaries got smoother by increasing $\mathrm{Y}$ amount, which may be attributed to Al-Y and Ca-Y-P phases existing between the matrix grains [10]. By glassy phase formation, the amount of interfering obstacles of grains decrease and sudden grain growth at relatively high temperature of $1600^{\circ} \mathrm{C}$, 
which gives rise to relative density from $94 \% \pm 0.7$ to $98.8 \% \pm 0.55$, is observed. Variations in relative density and micro-hardness in $\mathrm{HA} / \mathrm{Al}_{2} \mathrm{O}_{3}$ composites with different $\mathrm{Y}_{2} \mathrm{O}_{3}$ contents are shown in Fig. 5 .

\section{Conclusions}

The composites with equal weight ratios of the powders of $\mathrm{HA}$ (derived from bovine bone ) and $\mathrm{Al}_{2} \mathrm{O}_{3}$, with varying concentrations of $\mathrm{Y}_{2} \mathrm{O}_{3}$, were produced using a conventional powder metallurgy route and sintered successfully at $1600{ }^{\circ} \mathrm{C}$ for $4 \mathrm{~h}$. The increasing $\mathrm{Y}_{2} \mathrm{O}_{3}$ amount increased the glassy phase formation, as was evident from both, the FE-SEM and XRD evaluation. The hardness of samples with increasing $\mathrm{Y}_{2} \mathrm{O}_{3}$ amounts had increased by increasing glassy phase formation, which leads to the existence of Ca-Y-Al-P related phases. The relative density of samples increased from $94 \%$ to $98.8 \%$ of theoretical density, with the homogeneous distribution of glassy phase and more smooth surface, resistant to cracking. The reproducible microhardness, phase analyses and morphological evaluation suggest that these materials would have good performance in load bearing applications.

\section{References}

[1] P.V. Giannoudis, H. Dinopoulos, E. Tsiridis, Injury 36, 20 (2005).

[2] X. Li, L. Wang, Y. Fan, Q. Feng, F.Z. Cui, F. Watari, J. Biomed. Mater. Res. 101, 2424 (2013).

[3] J.H.G. Rocha, A.F. Lemos, S. Agathopoulos, P. Valèrio, S. Kannan, F.N. Oktar, J.M.F. Ferreira, Bone 37, 850 (2005).

[4] M. Jarcho, Clin. Orthop. Relat. Res. 157, 259 (1981).
[5] K. De Groot, C.P.A Klein, J.G.C Wolke, J.M.A. De Blieck-Hogervorst, Handbook of bioactive ceramics, vol. 2, CRC Press, Boca Raton 1990.

[6] L. Hong, H.C. Xu, K. De Groot, J. Biomed. Mater. Res. 26, 7 (1992).

[7] J.T. Edwards, J.B. Brunski, H.W. Higuchi, J. Biomed. Mater. Res. 36, 454 (1997).

[8] G. Goller, F.N. Oktar, Mater. Lett. 56, 142 (2002).

[9] Z.E. Erkmen, Y. Genc, F.N. Oktar, J. Am. Ceram. Soc. 90, 2885 (2007)

[10] K.E. Öksüz, A. Özer, Dig. J. Nanomater. Biostruct. 11, 167 (2016).

[11] L.L. Hench, E.C. Ethridge, Biomaterials: An interfacial Approach, Academic Press, New York 1982, p. 384 .

[12] B. Masson, R. Rack, G. Willmann, H.G. Pfaff, Biomech. Biomater. Ortop. 14, 143 (2004).

[13] A.F. Lemos, J.M.F. Ferreira, Key Eng. Mater. 254256, 1037 (2004).

[14] F.N Oktar, M. Yetmez, S. Agathopoulos, G. Lopez, G. Goller, I. Peker, J.M.F. Ferreira, J. Mater. Sci: Mater. Med. 17, 1161 (2006).

[15] J. Chevalier, Biomater. 27, 535 (2006).

[16] J. Chevalier, S. Deville, E. Munch, R. Jullian, Biomater. 25, 5539 (2004)

[17] A.B. Khalil, S.W. Kim, Y.K. Kim, Mater. Sci. Eng. A 456, 368 (2007).

[18] British Standard Non-metallic materials for surgical implants, Part 2, Specification for ceramic materials based on alumina, BS (No 7253), Part 2, ISO 64741981 (1990)

[19] C. Vasconcelos, Sintering of Ceramics - New Emerging Techniques, Publisher-Intech, 2012. 